\title{
Internasionalisasi dan Internalisasi Wacana War on Terror
}

\author{
Ambrosius Yustinus Kedang* \\ tommykedang@gmail.com
}

\begin{abstract}
Abstrak
Peristiwa 9/11 menimbulkan reaksi tegas dari Amerika Serikat (AS). AS melalui Presiden Bush dalam pidatonya pada tanggal 20 September 2001 menyatakan perang melawan terorisme "War On Teror". Pernyataan ini dengan cepat menginternasional dan menginternalisasi negara-negara di dunia termasuk Indonesia. War On Teror mengkonstruksi dunia, memberikan identitas, norma, tingkah laku dan kepentingan yang baru bagi aktoraktor dalam hubungan internasional dan bagi komunitas internasional. Wacana War on Terror kemudian mendorong masing-masing negara untuk membentuk berbagai aturan (norma) dan lembaga untuk mendukung War on Terror. Aturan-aturan ini mengatur pola tingkah laku dalam negara tersebut dan mengatur dan membentuk pola tingkah laku negara tersebut dalam menjalin hubungan dengan negara lain dalam komunitas internasional. Dengan teori konstrukstivis, khususnya melalui analisis wacana, penulis menunjukkan proses bagaimana wacana $W$ ar on Terror menjadi suatu norma internasional dan diinternalisasi oleh berbagai negara di luar Amerika sebagai norma domestiknya. Secara khusus penulis mengangkat Indonesia sebagai contoh proses internalisasi wacana $W$ ar on Terror.
\end{abstract}

Kata Kunci: Internalisasi, Internasionalisasi, Konstruktivis, Wacana War on Terror.

\begin{abstract}
The events of 9/11 cause reactions firmly from America. America through President; Bush in his speech on September 20, 2001 declared war against terrorism "War On Terror". This statement has been quickly internationalized and internalized the countries in the world including Indonesia. War On Terror the construction world, give identity, norms, behaviors and interests of new actors in international relations and for the international community. Discourse about $W$ ar on Terror forces every country to make some rules and institutions to support $W$ ar on Terror. These rules regulate the pattern of attitude of the country and also regulate and shape the pattern of attitude of the country in making relations with other countries in international communities. With Constructivism, In particular with discourse analysis the author shows the process of how the discourse of War on Terror becomes an international norm and internalized by many countries outside the United States as its domestic norms. In particular the author raised the Indonesia as an example of the process of internalization of the discourse of War on Terror.
\end{abstract}

Keywords: Constructivism, Discourse War on Terror, Internalization, Internationalization.

\section{Pendahuluan}

Pada tanggal 11 September 2001 dua situs penting Amerika yaitu Pentagon dan World Trade Center (WTC) diserang oleh kelompok yang disebut sebagai

*Korespondensi: Alumni Pascasarjana Ilmu Hubungan Internasional, Universitas Gadjah Mada. Jalan Kaliurang Km 7,5. Gang Bakalan No. 08 RT 005, RW 035, Ngabean, Kulon- Sinduharjo, Ngaglik,

Sleman. Email: tommykedang@gmail.com 
teroris (Kean, 2002: 285). Peristiwa ini menimbulkan kerugian jiwa dan material yang sangat besar (Kean, 2002: 285, 290-291, 293). Peristiwa di World Trade Center mengakibatkan 2.753 orang yang tewas ketika pesawat American Airlines Flight 11 dan United Airlines Flight 175 menabrak menara utara dan dan menara selatan WTC. Sebagian besar korban merupakan penumpang pesawat termasuk para pembajak dan para pegawai bangunan serta pengunjung WTC. Selain itu terdapat juga 343 orang pemadam kebakaran Kota New York, 23 orang lainnya adalah polisi Kota New York, dan 37 lainnya adalah petugas di Otoritas Pelabuhan. Para korban berusia berkisar dua sampai 85 tahun. Sekitar 75-80 persen korban adalah laki-laki. Sementara di Pentagon, Washington, 184 orang tewas ketika American Airlines Flight 77 yang dibajak, menabrak gedung Departemen Pertahanan AS itu. Di Pennsylvania, 40 penumpang dan awak kapal United Airlines Flight 93 tewas saat pesawat jatuh di sebuah lapangan (Manan, 2013).

Secara ekonomi Amerika Serikat mengalami kerugian ekonomi US\$ 123 miliar - Estimasi kerugian ekonomi selama 2-4 minggu setelah menara World Trade Center runtuh di New York City. Kerusakan situs WTC, termasuk kerusakan bangunan sekitarnya, dan infrastruktur kereta bawah tanah diperkirakan mencapai US $\$ 40$ miliar Klaim asuransi yang timbul akibat serangan 9/11 mencapai US\$ 9,3 miliar. Pembersihan di Ground Zero (bekas reruntuhan menara WTC) resmi berakhir pada 30 Mei 2002. Butuh 3,1 juta jam kerja untuk membersihkan 1,8 juta ton puingpuing. Total biaya pembersihan US\$ 750 juta (Manan, 2013).

Peristiwa ini dengan cepat ditanggapi oleh Amerika Serikat dengan menyatakan perang terhadap teroris yang diklaim sebagai pelaku yang bertanggung jawab atas peristiwa 9/11. Pernyataan perang ini tampak jelas dalam deklarasi $W$ ar on Terror yang disampaikan Bush dalam pidatonya pada 20 September 2001. Bush menyatakan: "Our enemy is a radical network of terrorists, and every government that supports them. Our war on terror begins with al Qaeda, but it does not end there. It will not end until every terrorist group of global reach has been found, stopped and defeated' (Bush, 2001: b).

Deklarasi ini dengan cepat menjadi suatu wacana yang diterima oleh penduduk Amerika sendiri dan berbagai negara di luar Amerika. Wacana War on Terror menggerakkan Amerika, organisasi-organisasi internasional, regional maupun 
negara-negara di luar Amerika untuk membentuk lembaga dan aturan yang mendukung War on Terror yang dideklarasikan Amerika.

Fenomena ini menimbulkan pertanyaan, Mengapa dan bagaimana wacana $W$ ar on Terror diterima secara internasional, menjadi norma internasional dan diinternalisasi sebagai norma oleh negara-negara di luar Amerika? Pertanyaan ini akan dijawab penulis dengan menggunakan perspektif konstruktivis. Tulisan ini terdiri dari empat bagian besar yaitu bagian pertama, menjelaskan latar belakang dan teori yang dipakai dalam tulisan ini. Bagian kedua akan dipaparkan tentang bagaimana wacana War on Terror mempengaruhi komunitas internasional (menginternasionalisasi) dan membentuk norma di berbagai negara di dunia (internalisasi). Bagian ketiga; secara khusus menunjukkan proses internalisasi wacana War on Terror di Indonesia. Bagian keempat merupakan kesimpulan

\section{Dekalarasi War On Teror sebagai Wacana}

Wacana adalah suatu konsep yang digunakan dalam berbagai makna yang berbeda. Terdapat tiga tingkatan pembedaan wacana. Pertama, secara sempit, menurut etimologis atau akar katanya. Wacana dalam level ini hanya berarti pidato atau perang kata (perdebatan). Konsep ini kemudian dihubungkan dengan konsep diskusi, risalah, percakapan dan pertukaran ide. Kedua, dalam tingkat yang lebih tinggi yaitu pada level semantik. Wacana digunakan umumnya dalam arti yang lebih komprehensif dalam teori ilmiah atau diskusi yang mewakili atau menunjukkan suatu mazhab tertentu. Ketiga, dalam cara dan konteks yang lebih luas dan lebih komprehensif, wacana dapat dimengerti dan dilihat dalam arti yang luas sebagai prinsip yang mengacu pada setiap jenis tatanan simbolik dalam proses komunikasi dan pembangunan pengertian. Dalam konteks wacana juga menunjuk pada penafsiran oleh suatu kelompok masyarakat yang membentuk dan menentukan keberadaannya (Neubert dan Reich, 2002: 2-3).

James Paul Gee (2011: 28-29) menggunakan huruf kapital pada kata Discourse untuk menunjukkan kombinasi dan kesatuan bahasa, tindakan, interaksi, pandangan, kepercayaan, penilaian dan penggunaan berbagai simbol, alat dan obyek untuk membentuk pengenalan dan pemahaman sosial terhadap suatu identitas. Masyarakat membangun identitasnya tidak hanya melalui bahasa tetapi juga dengan 
menggunakan atau dipadukan dengan unsur-unsur lain misalnya tindakan dan kepentingan.

Dalam konteks pembahasan tentang wacana War on Terror: "Our war on terror begins with al Qaeda"(Bush, 2001: b), secara sempit wacana dapat dipahami pada level pertama hanya sebagai suatu pidato, pidato yang disampaikan Bush pada 11 September dan 20 September 2001. Namun dalam konteks yang lebih luas, wacana War on Terror dapat dipahami pada level ketiga, wacana menunjuk pada semua bentuk simbolik dalam komunikasi dan pada penafsiran suatu kelompok tertentu yang menunjukkan identitas kelompok tersebut. Wacana War on Terror menunjukkan bentuk simbolis dari komunikasi yang dibangun Amerika dengan tujuan untuk membangun suatu pemahaman bersama, menunjukkan penafsirannya terhadap realitas 9/11 dan sekaligus pernyataan identitas Amerika. Dengan War on Terror masyarakat internasional telah memiliki gambaran tentang peristiwa 9/11, tanggapan Amerika terhadap peristiwa itu dan bagaimana mereka memahami dan bertindak terhadap $W$ ar on Terror.

Dalam bidang politik, bahasa sering digunakan sebagai sarana komunikasi politik untuk mengungkapkan pandangan pribadi dari politisi atau dari kelompok tertentu, membentuk opini dan memperoleh dukungan dari publik. Bentuk bahasa yang sering digunakan dalam bidang politik adalah pidato. Dalam bidang politik, setiap pidato memiliki dua aspek. Pada aspek pertama yaitu dari aspek pembicara. Setiap pidato yang disampaikan oleh seorang politisi merupakan ungkapan dari keinginan sang politisi. Setiap pidato juga memiliki fungsinya masingmasing. Secara umum dapat dikatakan bahwa sebagai pembicara baik itu politisi menggunakan bahasa untuk mencapai tujuan tertentu misalnya mengungkapkan keinginannya.

Dengan demikian, bahasa menjadi alat yang sangat penting dalam masyarakat politik yang digunakan untuk membangun kesadaran kelompok dan mempererat kelompok itu dengan membuat dan meyakinkan mereka bahwa mereka dan suara mereka dihitung. Dengan kata lain, di satu sisi melalui pidato politik, politisi mencoba untuk melibatkan semua warga dalam proses pengambilan keputusan. Di lain sisi, sebagai penerima, pendengar menafsirkan teks atau ucapan dalam pidato yang disampaikan oleh politisi sebagai pembicara dengan 
memanfaatkan pengetahuan intertekstual dan politik yang mereka punyai (Wlodarek, 2010: 142).

Wacana memiliki kaitan erat dengan bahasa, bahasa menjadi elemen penting dalam wacana. Dalam kaitan dengan teori konstruktivis, bahasa merupakan saran untuk membangun pemahaman bersama "pemahaman intersubjektif." Kaum konstruktivis berpendapat bahwa penyebaran (shared) ide, keyakinan dan nilai mempengaruhi tindakan sosial dan politik serta membentuk struktur dunia (ReuSmit, 2005: 196). Penyebaran keyakinan ini terjadi melalui komunikasi antara aktor dengan menggunakan bahasa. Peranan bahasa dalam teori konstruktivis secara khusus dibahas oleh Nicholas Onuf. Bagi Onuf, konstruktivis dimulai dengan perbuatan (deeds) (Onuf, 1989: 35). Elemen utama dari perbuatan (deeds) ini adalah pembicaraan (speechacts). Pembicaraan (speech acts) melalui pengulangan dan pelembagaan menjadi aturan dan dengan demikian memberikan konteks dan makna dasar bagi tindakan manusia (Zehfuss, 2004: 151).

\section{Konstruksi Wacana War on Terror}

Konstruktivis meyakini dunia dalam hal ini tatanan atau struktur internasional, identitas dan kepentingan aktor merupakan hasil konstruksi sosial dari masyarakat dan realitas atau struktur tersebut masyarakat kemudian mengonstruksi masyarakat atau aktor (Reus-Smit, 2005: 197). Dunia sosial merupakan wilayah intersubjektif yang dibentuk oleh masyarakat dalam waktu dan tempat tertentu (Jackson dan Sorensen, 2009: 307).

Identitas dan kepentingan tak bisa dipisahkan dari situasi sosial. Identitas dan kepentingan adalah hasil dari konstruksi sosial yang terbentuk melalui interaksi antara aktor. Hal ini dapat terjadi karena adanya pengetahuan dan pengertian bersama yang dalam konstruktivis disebut "pemahaman intersubjektif." Pemahaman intersubjektif dibentuk melalui proses pemberian tanda atau isyarat (signaling), interpretasi dan tanggapan terhadap tanda yang diberikan. Proses ini terjadi dalam interaksi para aktor. Dalam proses interaksi aktor menggunakan bahasa lisan maupun tulisan dan tindakan untuk memberikan tanda, interpretasi dan tanggapan (Folker, 2006: 116). Dengan demikian dapat dikatakan bahwa wacana berperan dalam 
pembentukan pemahaman intersubjektif yang membentuk identitas dan kepentingan aktor.

Konstruktivis berpendapat bahwa struktur internasional ditentukan dan dibentuk oleh distribusi internasional ide dan pemahaman. Distribusi ide dan pemahaman inilah yang memberikan struktur pada dunia dan membentuk identitas aktor dan dunia (Puschkarsky, 2009: 13). Distribusi ide dan pemahaman ini terjadi melalui interaksi dan komunikasi antara aktor dengan mengomunikasikan ide dan pemikiran mereka melalui penggunaan bahasa dan wacana.

Nicholas Greenwood Onuf menegaskan peranan bahasa dalam konstruktivis. Onuf mengembangkan dan membangun teori konstruktivisnya dari pengembangan teori Anthony Giddens. Bahasa adalah pusat dalam analisis Onuf. Bahasa tidak hanya menggambarkan atau mewakili realitas, melainkan menciptakan realitas (Zehfuss, 2004: 153). Onuf menekankan bahwa manusia membangun realitas melalui perbuatannya. Perbuatan ini nyata dalam tindakan berbicara, pidato atau berkomunikasi (Zehfuss, 2004: 151). Pembicaraan atau pidato akan membentuk dan mempengaruhi tindakan orang lain. Pembicaraan menggerakkan orang untuk bertindak. Dengan demikian bahasa menunjukkan aspek performatif dan deskriptif (Zehfuss, 2004: 21).

Onuf mengelompokkan pidato atau pembicaraan dalam tiga kategori yaitu: penegasan (assertive), petunjuk (directives), tindakan (commissives). Pertama, penegasan (assertive), adalah pernyataan keyakinan yang, dengan implikasi, pembicara ingin para pendengar untuk menerima. Kedua, petunjuk (directives) berisi tindakan pembicara ingin pendengar untuk melakukan. Ketiga, tindakan (commissives) terdiri dalam deklarasi komitmen pembicara untuk beberapa tindakan di masa depan (Zehfuss, 2004: 154).

Dalam wacana $W$ ar on Terror ketiga unsur ini dapat ditemui dengan jelas. Pertama, penegasan (assertive) tampak saat Bush meyakinkan dan menawarkan berbagai nilai dan keyakinan yang ada pada Amerika dan telah diterima secara umum, misalnya nilai kebebasan. Nilai ini kemudian diterapkan dalam kelompok baru, kelompok Kita. Kedua, petunjuk (directives), Amerika memberikan petunjuk bagaimana mengatasi terorisme yaitu dengan membangun kerja sama global. Ketiga, tindakan (commissives), implikasi dari semuanya itu maka dibentuklah berbagai aturan 
dan kerja sama yang melahirkan peraturan- peraturan, undang-undang (norma) yang mendukung perang global melawan terorisme.

Melalui wacana $W$ ar on Terror Bush membentuk pemahaman intersubjektif atau pemahaman bersama dunia bahwa terorisme merupakan suatu kejahatan terhadap kemanusiaan dan merupakan ancaman bagi keamanan internasional maka terorisme harus diperangi bersama. Pembangunan pemahaman bersama ini tampak jelas dalam wacana baik dan jahat. Melalui wacana ini Bush membangun atau mengonstruksi dunia bahwa terorisme adalah jahat. Bush menggunakan bahasa dalam pidato dan pidato itu sendiri untuk membentuk realitas dunia. Dengan demikian bahasa tidak hanya menggambarkan atau mewakili realitas, melainkan menciptakan realitas (Zehfuss, 2004: 153).

Dengan kata lain, Bush menggunakan kata-kata (pidato) untuk membangun dan membentuk pemahaman tentang yang "Benar" dan "Salab", "Baik" dan "Jahat" dalam perang melawan terorisme. Pembentukan pemahaman tentang "Benar" dan "Salab", "Baik" dan "Jahat" telah muncul pada pidato Bush yang pertama, 11 September 2001, "Today, our nation saw evil, the very worst of human nature ..”(Bush, 2001: a). Pernyataan ini semakin dipertegas dalam pidato kedua, 20 September 2001,

“The terrorists' directive commands them to kill Christians and Jews, to kill all Americans, and make no distinction among military and civilians, including women and children... They are (terrorist) sent back to their homes or sent to hide in countries around the world to plot evil and destruction... We have seen their kind before. They are the heirs of all the murderous ideologies of the 20th century. By sacrificing human life to serve their radical visions--by abandoning every value except the will to power--they follow in the path of fascism, and Nazism, and totalitarianism. And they will follow that path all the way, to where it ends: in history's unmarked grave of discarded lies"(Bush, 2001: b).

Bush mengelompokkan teroris sebagai yang jahat karena tindakan teror, metode dan tindakan mereka menampilkan kejahatan dan membenci nilai-nilai universal seperti kebebasan, kedamaian dan keamanan. Pengelompokan ini jelas dalam pernyataan Bush:

"Today, our nation saw evil, the very worst of human nature" (Bush, 2001:a) ... They (terrorist) are sent back to their homes or sent to hide in countries around the world to plot evil and destruction... They hate our freedoms--our freedom of religion, our freedom of speech, our freedom to vote and assemble and disagree with each other..."(Bush, 2001: b). 
Melalui pernyataan tersebut Bush membangun simpati dunia dengan meyakinkan dunia bahwa teroris adalah ancaman bagi kemanusiaan karena mereka membenci nilai-nilai kebebasan, kemanusiaan dan keamanan "They hate our freedoms-our freedom of religion, our freedom of speech, our freedom to vote and assemble and disagree with each other..."(Bush, 2001:b). Oleh karena teroris adalah kelompok yang "Jahat" maka Amerika Serikat mengajak negara-negara lain untuk bergabung bersama Amerika Serikat untuk memerangi terorisme sebagai yang "Tahat".

"..We ask every nation to join us"..We will ask, and we will need, the help of police forces, intelligence services, and banking systems around the world. The United States is grateful that many nations and many international organizations have already responded--with sympathy and with support. Nations from Latin America, to Asia, to Africa, to Europe, to the Islamic world. ......Perhaps the NATO Charter reflects best the attitude of the world: An attack on one is an attack on all. ." (Bush, 2001, b)

Negara-negara mulai melihat dunia ini terbagi dalam dua kelompok yaitu kelompok teroris yang salah dan jahat yang harus diperangi dan kelompok yang benar yang harus diikuti. Pemahaman tentang dunia akan mengarahkan atau menghasilkan tindakan tertentu misalnya bergabung dengan salah satu kelompok atau membentuk dan menyesuaikan peraturan, identitas dan kepentingan dengan kelompok yang diikuti (Solheim, 2006: 10).Dengan demikian dapat dikatakan bahwa dengan membangun pemahaman bersama bahwa terorisme merupakan kejahatan melalui pemaparan argumen dan bukti maka wacana $W$ ar on Terror mulai menyebar keluar dari Amerika ke seluruh belahan dunia; wacana War on Terror telah menginternasionalisasi.

Pada titik lain, Onuf menunjukkan bagaimana suatu bahasa, pidato dapat membentuk identitas suatu negara. Onuf mengartikan pidato sebagai tindakan berbicara yang menggerakkan seseorang untuk bertindak. Pengertian yang diberikan Onuf ini, tampak aspek performatif bahasa dari pada deskriptif. Keberhasilan pidato ini tergantung dari tanggapan pendengar. Jika pidato terus diulang ulang akan menjadi konvensi. Pengulangan ini terjadi melalui peran media yang secara terusmenerus menyampaikan wacana tersebut. Pembicaraan atau pidato yang diulang terus menerus akan dilembagakan menjadi aturan dan dengan demikian memberikan 
konteks, dasar dan makna pada tindakan aktor (Zehfuss, 2004: 151 ). Suatu pidato memiliki konsekuensi normatif, di mana pidato tidak hanya mengubah situasi tapi juga mendefinisikan identitas mereka. Implikasi dari pidato adalah bahwa pendengar harus menerima keyakinan yang dibawa oleh pembicara yang diwujudkan dalam tindakan mereka sesuai dengan nilai dari pembicara (Zehfuss, 2004: 171). Saat aktor menerima bahwa mereka harus melakukan sesuatu yang harus mereka lakukan berulang-ulang maka konvensi akan menjadi aturan. Aktor akhirnya mengakui bahwa mereka harus mengikuti aturan karena mereka adalah aturan itu dan tidak ada alasan lain untuk tidak melakukannya (Zehfuss, 2004: 20-21). Proses dapat disebut juga proses internalisasi.

Wacana War on Terror yang telah diinternasionalisasi diulang secara terusmenerus oleh media dalam berbagai kesempatan. Wacana ini menggerakkan Amerika Serikat, organisasi internasional dan negara-negara lain untuk bertindak membentuk aturan-aturan dalam memerangi terorisme. Amerika Serikat sendiri mulai membangun dan membentuk aturan dan lembaga domestik untuk memerangi terorisme. Pada tingkat domestik didirikan lembaga seperti Anti-Terrorism Task Forces dan Foreign Terrorist. Tracking Task Force. Anti-Terrorism Task Forces dibentuk dengan tujuan mengumpulkan informasi dan mengorganisasi penaganan terorisme di negaranegara bagian. Foreign Terrorist Tracking Task Force dibentuk dengan tujuan untuk menghalangi masuknya teroris ke suatu negara, menemukan, dan menghapus terorisme di suatu negara (The Coalition Information Center , 200: 14). Selain itu, dibentuk juga beberapa lembaga lain yaitu The Department of Homeland Security, The Patriot Act, the Senate Committee Investigation into 9/11, dan the National Commission on Terrorist Attacks Upon the United States (Fulton, 2004: 65).

Secara internasional tampak dalam resolusi yang dikeluarkan Dewan Keamanan PBB. Dewan Keamanan PBB mengeluarkan resolusi-resolusi yang mendukung kampanye Amerika Serikat melawan terorisme resolusi itu antara lain resolusi 1368, resolusi 1377 dan resolusi 1373. Melalui resolusi-resolusi ini Amerika Serikat semakin memperoleh legitimasi untuk melakukan perang melawan terorisme. Bahkan dapat dikatakan bahwa Dewan Keamanan telah menjadi instrumen Amerika Serikat untuk melegalkan War on Terror (Koechler, 2002:1). Secara regional, misalnya kerja sama Amerika dengan Uni Eropa. Sejak serangan tahun 2001, Uni Eropa 
berusaha meningkatkan ketahanannya terhadap ancaman terorisme dengan membuat berbagai langkah. Salah satunya dan menjadi prioritas utama adalah membangun kerja sama dengan Amerika. Uni Eropa dan Amerika berusaha meningkatkan kerja sama dengan membentuk berbagai aturan baru. Pada tahun 2001 dan 2002, AS-Europol menghasilkan dua perjanjian yang menyimpulkan dan memungkinkan otoritas penegakan hukum AS dan Europol (kepolisian Eropa) untuk berbagi informasi strategis dan informasi pribadi (Archick, 2011:1-4).

Selain itu, Uni Eropa membentuk EU Action Plan to Fight Terrorism yang berisi rencana aksi dari Uni Eropa untuk memerangi terorisme. Rencana ini semakin diperkuat dengan Declaration on Combating Terrorism sebagai tanggapan terhadap peristiwa bom yang terjadi di Madrid pada 11 Maret 2004 (EU Plan of Action on Combating Terrorism) Eropa terhadap War on Terror nyata dalam pembentukan EU Action Plan to Fight Terrorism yang berisi rencana aksi dari Uni Eropa untuk memerangi terorisme yang semakin diperkuat dengan Declaration on Combating Terrorism sebagai tanggapan terhadap peristiwa bom yang terjadi di Madrid pada 11 Maret 2004 (EU Plan of Action on Combating Terrorism)

Aturan-aturan itu kemudian diikuti oleh negara-negara dan membentuk identitas mereka sebagai kelompok yang dalam wacana War on Terror disebut sebagai kelompok "Kita" negara-negara lain selain Amerika akhirnya mengakui dan mengikuti aturan-aturan itu karena mereka sadar aturan dan perjanjian itu telah membentuk identitas mereka.

Hal ini terjadi karena melalui wacana $W$ ar on Terror, Amerika dan Bush menawarkan keyakinan mereka tentang kebebasan, keadilan, persamaan dan keyakinan bahwa terorisme adalah kejahatan yang harus diterima dan diwujudkan dalam tindakan negara-negara lain sesuai dengan nilai dan keyakinan dari Amerika sebagai pembicara dan pembentuk wacana. Secara singkat dapat dikatakan bahwa melalui wacana $W$ ar on Terror Amerika mendefinisikan identitas negara-negara lain. Definisi ini kemudian diterima oleh negara lain sebagai identitas mereka. Dalam dan pada keadaan inilah wacana War on Terror telah menjadi bagian dan identitas dari negara-negara lain di luar Amerika; wacana War on Terror telah diinternalisasi oleh berbagai negara di luar Amerika yang membentuk identitas dan kepentingan mereka. 
Melalui wacana War on Terror Amerika membentuk pemahaman bersama dan membentuk realitas dunia. Amerika memberikan identitas baru pada dunia sebagai dunia yang sedang berperang melawan terorisme. Dunia kini dikenal dengan realitas sebagai suatu perang melawan terorisme. Identitas baru yang semula adalah definisi dan identitas yang diberikan Amerika ini kemudian diterima dan diyakini berbagai negara sebagai identitas barunya yang kemudian membentuk tingkah lakunya dalam War on Terror.

\section{Produk Konstruksi Wacana War on Terror}

Wacana War on Terror menghasilkan institusionalisasi norma, dan perubahan geopolitik dunia. Dunia kemudian dibagi menjadi dua kelompok, teroris dan kontra teroris. Produk-produk ini menjadi bukti bahwa wacana $W$ ar on Terror telah diinternasionalisasi dan diinternalisasi oleh berbagai negara di luar Amerika.

Wacana War on Terror menginternasionalisasi dan menginternalisasi karena adanya proses konstruksi yang dibangun oleh Amerika. Proses konstruksi ini terjadi melalui komunikasi, penggunaan bahasa (wacana). Melalui wacana War on Terror dibangun dan dibentuk pemahaman bersama bahwa terorisme adalah jahat dan terorisme merupakan ancaman bersama yang harus ditangani bersama. Pemahaman bersama ini menggerakkan berbagai negara di luar Amerika dan organisasi internasional untuk membentuk dan menghasilkan aturan-aturan (norma) berupa undang-undang, resolusi dan perjanjian yang mendukung pemahaman bersama bahwa terorisme adalah kejahatan atau bahaya yang mengancam keamanan dunia dan kemanusiaan secara khusus terorisme menjadi bahaya bagi keamanan nasional masing-masing negara. Berbagai aturan ini kemudian memberikan konteks, dasar dan makna pada tindakan masing-masing negara atau aktor dan membentuk identitas negara masing-masing dalam komunitas internasional. Wacana War on Terror menampilkan identitas, way of life Amerika dan membentuk identitas dunia. Pengonstruksian menghasilkan penguatan dominasi Amerika dalam komunitas internasional, institusionalisasi norma dan perubahan geopolitik dunia yang tampak dalam new bipolar.

\section{Internalisasi Wacana War on Terror di Indonesia}


Proses internalisasi Wacana War on Terror di Indonesia ini dimulai saat kunjungan presiden Megawati ke Amerika Serikat. Pada tanggal 19 September 2001, Presiden Indonesia, Megawati Soekarno Putri melakukan kunjungan ke Amerika. Dalam kunjungan itu Bush menawarkan dan mengajak Indonesia untuk masuk dan bergabung dalam Anti terrorism Assistance (ATA). Program ATA ini bertujuan untuk memberikan bantuan kepada negara-negara mitra dengan memberikan pelatihan kontra terorisme dan peralatan, meningkatkan hubungan bilateral, dan meningkatkan penghormatan terhadap hak asasi manusia (GAO, 2008: i). Selain itu dalam pertemuan tersebut Bush menawarkan bantuan ekonomi pada Indonesia berupa dana sebesar 130 juta dolar Amerika untuk keuangan pada tahun 2002 dan bantuan 10 juta dolar untuk pelatihan Polisi Indonesia (Wise, 2005 : 26).

Megawati menanggapinya dengan memberikan janji untuk mendukung dalam $W$ ar on Terror dan menjanjikan untuk memperkuat kerja sama Indonesia Amerika dalam War on Terror (Wise, 2005: 26). Megawati dalam Joint Statement dan dalam pernyataannya di Washington DC, 19 September 2001 menyatakan kesiapan Indonesia bergabung dalam $W$ ar on Terror.

"Today, I had very productive talks with President Bush in the oval office. I told him what I wish to tell you tonight: that we mourn with America, that we share your grief and outrage, and that we strongly condemn terrorism in all its forms and manifestations. Indonesia is ready to cooperate with the United States and other civilized countries on counter-terrorism" (Siregar, 2001).

Keputusan Megawati untuk bergabung dalam War on Terror ini mendapat penolakan domestik dari elit politik dan kelompok Muslim sebagai kelompok mayoritas. Masyarakat Indonesia yang sebagian besar penduduknya adalah Muslim, sejak peristiwa 9/11 telah terbentuk suatu konsep bahwa $W$ ar on Terror adalah perang melawan Muslim atau bahkan dikatakan sebagai perang Barat melawan Islam (Kay, 2005: vi). Selain itu, telah lama muncul kecurigaan dalam pemikiran masyarakat Indonesia yang menjurus pada sikap anti Amerika Serikat. Sikap anti Amerika Serikat ini semakin diperkuat dengan serangan yang dilakukan Amerika Serikat terhadap Irak dan Afghanistan.

Serangan Amerika Serikat terhadap Afghanistan menimbulkan serangkaian penolakan dan demonstrasi besar-besaran oleh kelompok Muslim di 
Indonesia. Para aktivis melakukan demonstrasi di depan kedutaan Amerika Serikat sambil menyerukan "Tuhan itu agung" dan "usir Amerika, usir kapitalis." Kurang lebih 4,000 menyerukan penolakan terhadap serangan Amerika Serikat ke Afghanistan dan meminta Megawati untuk memutuskan hubungan diplomatik dengan Amerika Serikat. Din Syamsuddin, sekretaris jenderal Majelis Ulama Indonesia (MUI) mengajak semua umat Muslim Indonesia untuk melakukan jihad melawan Amerika jika Amerika kembali menyerang Afghanistan. Selain itu, menurut laporan kedutaan Amerika, DDII menekan 10 kelompok radikal Islam melakukan konferensi pers di masjid al-Furqan Jakarta dan mengancam akan melakukan jihad jika Amerika Serikat kembali menyerang Afghanistan. Muhammad Kalono, seorang dari kelompok Islam yang bersifat militer mengatakan "Jika Amerika menjatuhkan sebuah peluru di Afghanistan, atas kehendak Tuhan, kami akan melenyapkan semua fasilitas dan kepentingan Amerika di Indonesia, sementara ini kelompok pemuda Islam mengancam akan membunuh duta besar Amerika, Gelbard jika Amerika kembali menyerang Afghanistan" (Kay,2005:18).

Penolakan juga tampak dari tokoh politik Islam misalnya oleh Hamzah Haz. Hamzah Haz di dalam masjid di Jakarta sehari setelah terjadi peristiwa 9/11 di Amerika bahkan mengatakan tidak ada teroris di Indonesia (Wise, 2005:27). Penolakan ini juga disampaikan oleh organisasi Islam misalnya oleh MUI. Atas serangan terhadap Irak dan Afghanistan ini, MUI pada tanggal 25 September 2001 mengeluarkan deklarasi untuk perang suci terhadap Amerika dan sekutunya yang melakukan serangan ke Irak dan Afghanistan (Desker, 2002 :12).

Penolakan ini terjadi karena mereka berpendapat bahwa $W$ ar on Terror sama dengan memerangi Islam yang adalah mereka dan saudara-saudaranya(Kay, 2005: vi). Kecurigaan dan anti Amerika muncul karena ada kesan bahwa Amerika Serikat berusaha untuk melemahkan Islam. Masyarakat Indonesia curiga bahwa Amerika, melalui CIA terlibat dalam sejumlah pemberontakan di Indonesia pada tahun 1950 dan berperan dalam kudeta yang menjatuhkan Sukarno (Asia Pacific Center for Security Studies, 2003:4). Berbagai hal tersebut menunjukkan bahwa sampai pada titik ini dapat dikatakan usaha untuk mempromosikan War on Terror ke Indonesia mendapat halangan yang cukup besar meskipun Megawati telah menyatakan bahwa Indonesia siap bergabung dalam War on Terror. 
Untuk mengatasi penolakan tersebut, Amerika Serikat melakukan persuasi melalui media, pembentukan lembaga kerja sama anti terorisme dan pemberian bantuan ekonomi kepada Indonesia (Wise, 2005: 26). Amerika Serikat melakukan persuasi melalui media komunikasi khususnya dengan berbagai iklan (Asia Pacific Center for Security Studies, 2003: 4) dan dengan menggunakan berbagai institusi misalnya Anti Terrorism Assistance (ATA) (Wise, 2005: 39-40).

Amerika Serikat menggunakan media penyiaran internasional dalam hal ini televisi sebagai suatu sarana untuk melakukan persuasi, mempengaruhi dan membentuk pandangan masyarakat Muslim di seluruh dunia dan Indonesia khususnya. Departemen Luar Negeri Amerika telah meluncurkan serangkaian iklan televisi di Indonesia. Iklan ini berisi tentang kehidupan Muslim di Amerika Serikat yang berbicara tentang kehidupan mereka di Amerika Serikat secara khusus tentang kebebasan mereka untuk menjalankan agama mereka di Amerika (Asia Pacific Center for Security Studies, 2003: 4).

Pemerintah Amerika Serikat telah melancarkan kampanye iklan sebanyak 15 juta dolar untuk menunjukkan bahwa Amerika Serikat toleran terhadap Islam. Iklan pertama akan dilancarkan di Indonesia, negara yang penduduk muslimnya paling banyak di dunia, sebelum permulaan bulan suci Ramadhan pada awal November. Iklan televisi selama dua menit menayangkan kehidupan orang-orang Muslim Amerika. Salah satunya memperlihatkan Doktor Elias Zerhouni, Amerika kelahiran Aljazair, yang diangkat oleh Presiden Bush untuk mengepalai Institut Kesehatan Nasional dekat Washington, D-C. Juru bicara Departemen Luar Negeri, Richard Boucher mengatakan, iklan itu dimaksudkan untuk memberikan gambaran kepada rakyat di luar negeri mengenai masyarakat Amerika dan bahwa orang Muslim bebas untuk menunaikan agama mereka. Selain itu Departemen Luar Negeri Amerika, Biro Informasi Internasional bahkan mengeluarkan buku dengan judul Kisah Muslim di Amerika. Buku yang menceritakan tentang kehidupan umat muslim di Amerika.(Amerika Melancarkan Kampanye Iklan Sebagai Toleransi Terhadap Islam, 2002).

Promosi War on Terror oleh Amerika Serikat juga didukung oleh lembaga khusus yaitu ATA. Lembaga ini mendapat dukungan dari institusi domestik atau dari pemimpin domestik. Di Indonesia, institusi utama ATA didukung oleh institusi 
domestik Indonesia yaitu Counter-Terrorism Coordinating Desk (CTCD). CTCD didirikan dengan tugas untuk merumuskan kebijakan dan strategi nasional untuk memerangi terorisme dan mengkoordinasikan tahap operasional yang diperlukan (Wise, 2005: 38). CTCD didirikan pada tanggal 22 Oktober 2002 berdasarkan Instruksi Presiden Megawati, No. 4. CTCD dipimpin oleh Menteri Koordinator Bidang Politik dan Keamanan, yang waktu itu dijabat oleh Susilo Bambang Yudhoyono (Wise, 2005: 38). Selain CTCD, berdasarkan suatu telegram rahasia No 217/IV/2003 pada tanggal 25 April 2003, Jenderal Dai Baktiar menandatangani pembentukan Direktorat VI/Anti-Teroris Satuan Bom di Direktorat Investigasi Kriminal di Markas Besar Polisi Republik Indonesia (Polri). Direktorat VI ini bertanggung jawab dalam pengembangan strategi dan kebijakan serta kontrol terhadap operasi anti terorisme di Indonesia. Direktorat VI merupakan cikal bakal dari Detasemen 88. Densus 88 satuan khusus kontra-terorisme yang dibangun dan diselenggarakan dengan bantuan Amerika melalui ATA pada tahun 2003 dan secara resmi didirikan pada tahun 2004 (Wise, 2005:39-40).

Krisis ekonomi yang dialami sejak 1997 membuat Indonesia sangat membutuhkan bantuan ekonomi. Dengan bergabungnya Indonesia dalam War on Terror, Indonesia menerima banyak bantuan dari Amerika Serikat. Amerika Serikat memberikan bantuan tambahan dan dukungan melalui reformasi demokratis, rekonstruksi pasca-tsunami, pendidikan dan kesehatan. Presiden Bush mengumumkan pemberian bantun pendidikan kepada Indonesia dalam kurun waktu 6 tahun sebesar 157 juta dolar Amerika. Amerika memfokuskan bantuan pada pengembangan pendidikan Islam misalnya dengan mengundang para kiai untuk berkunjung ke Amerika untuk mengikuti program pluralisme agama dan memberikan bantuan kepada universitas-universitas Islam misalnya kepada Universitas Muhammadiyah Yogyakarta (Kartini dan Dewi, 2005: 127-130).

Selain itu, pemerintah Amerika Serikat melalui sektor swasta Amerika membantu Indonesia mencapai kehidupan sosial yang setara dan menciptakan perkembangan ekonomi yang berkelanjutan melalui pembangunan seperti promosi pemerintahan yang baik (good governance), pengembangan sektor energi, dan pengembangan dan perluasan usaha kecil dan menengah, Amerika Serikat juga membantu memberdayakan perempuan dan mendorong pertumbuhan ekonomi dan 
kemandirian (Kay, 2005: vi). Meskipun Amerika Serikat berusaha dengan berbagai cara namun penerimaan $W$ ar on Terror di Indonesia belum diterima secara sepenuhnya. War on Terror masih di lihat sebagai perang Amerika Serikat dan sekutunya untuk melawan Islam.

Proses internalisasi $W$ ar on Terror di Indonesia mendapat momentum saat terjadi peristiwa bom Bali I, 12 Oktober 2002 (Wise, 2005: 3. dan CRS Report for Congress, 2005: 11). Pada 12 Oktober 2002 ,pukul 11:05 sebuah bom elektronik meledak Paddy Bar, sebuah café malam di Kuta Bali. Karena bom itu para pelanggan berlari ketakutan keluar dari tempat itu. Di luar café terjadi ledakan kedua dari bom yang ada dalam sebuah Mitsubishi minivan putih yang ada di depan Sari Club di seberang jalan. Bom ketiga meledak di dekat Konsulat AS. Peristiwa ini menimbulkan korban lebih dari 200 meninggal dan 300 lainnya luka-luka. korban sebagian besarnya adalah warga Australia, selain itu ada juga warga asing lain dan warga Indonesia (Wise, 2005: 3. dan CRS Report for Congress, 2005: 11).

Bom Bali menjadi titik balik yang mengubah cara pandang, pemahaman dan kebijakan Indonesia dalam menghadapi terorisme sekaligus membuka ruang lebar untuk masuknya War on Terror ke Indonesia (Tumanggor, 2007: 94). Para politisi dan pemimpin agama yang semula menyangkal keberadaan terorisme di Indonesia disadarkan dengan peristiwa ini. Hamzah Haz dengan cepat menarik pernyataannya yang menyangkal adanya ancaman teroris di Indonesia (Asia Pacific Center for Security Studies, 2003: 3). Bom Bali menyadarkan Indonesia bahwa terorisme ada dan bisa terjadi di "rumah" sendiri (Asia Pacific Center for Security Studies, 2003: 3). Bom Bali I menggerakkan pemerintah Indonesia untuk semakin meningkatkan kekuatan eksternal dan internal dalam mengatasi terorisme.

Secara internal Indonesia mengeluarkan berbagai peraturan dan undangundang misalnya Perppu No. 1 tentang Pemberantasan Tindak Pidana Terorisme, dan Perppu No. 2 Tahun 2002 tentang Pemberantasan Tindak Pidana Terorisme 2002 dan UU No. 15/2002 (Ramakrishna dan Tan, 2003: 363) serta pembentukan lembaga anti terorisme misalnya Densus 88 dan Pembentukan the Counter-Terrorism Coordinating Desk (CTCD) melalui Instruksi Presiden No 4 tahun 2002 (Wise, 2005: 8). 
Secara eksternal, Indonesia melakukan berbagai kerja sama internasional dan regional, meratifikasi instrumen hukum internasional dan regional tentang $W$ ar on Terror. Pada tingkat internasional Indonesia semakin memperkuat kerja sama internasional dalam memberantas terorisme dengan melaksanakan resolusi Dewan Keamanan PBB, resolusi 1368 tahun 2001 dan 1373 tahun 2001 (Tumanggor ,2007:93-94). Indonesia menunjukkan penyesuaiannya pada dengan komunitas internasional dengan mendukung dan berkomitmen memberikan kontribusi bagi upaya-upaya PBB dalam pemberantasan terorisme. Tindakan yang dibuat Indonesia yaitu berpartisipasi aktif dalam pembahasan draf Comprehensive Convention on International Terrorism serta berusaha agar perundingan itu dapat diselesaikan. Selain itu, Indonesia menunjukkan kemauan untuk penyesuaian dengan komunitas internasional dengan melaksanakan ketentuan hukum internasional mengenai pemberantasan terorisme.

Pada tahun 2001 Menteri Luar Negeri Indonesia Hassan Wirayuda menandatangani United Nations Convention on Combating Terrorism di kantor pusat PBB. Peristiwa ini menjadikan Indonesia sebagai negara ke 45 yang menerima perjanjian itu (Seniwati, Sani dan Nadaraja, 2012: 680). Keseriusan dalam penyesuaian ini juga tampak dalam keterlibatan Indonesia dalam The Counter-Terrorism Committee (CTC) dan melaksanakan resolusi Dewan Keamanan PBB, Resolusi 1368 dan 1373 tahun 2001 (Tumanggor, 2007:93-94). Keseriusan Indonesia ikut dalam program ini tampak dalam pemberian laporan kepada CTC yaitu pada tanggal 21 Desember 2001 dan pada tanggal 21 Juli 2002. Laporan kedua ini memuat penjelasan tentang perkembangan yang telah dicapai setelah laporan pertama, perkembangan itu nyata dengan adanya UU No. 15/2002 mengenai Kejahatan Pencucian Uang, tentang perkembangan rencana penyusunan undang-undang anti terorisme, dan proses persiapan ratifikasi International Convention for the Suppression of the Financing of Terrorism, Convention Against Transnational Crime dan Optional Protocol (Pernyataan Pers Menteri Luar Negeri Indonesia, 2003).

Secara nasional Indonesia memasukkan berbagai ketentuan internasional dalam undang-undang tentang terorisme khususnya dalam UU No. 15 tahun 2003. UU ini secara memuat secara spesifik juga memuat ketentuanketentuan yang ada pada Convention Against Terrorism Bombing (1997) dan Convention on 
the Suppression of Financing Terorism (1997) yang mencakup ketentuan yurisdiksi internasional dan trans nasional serta secara khusus tentang tindakan terhadap pidana terorisme internasional (Soetriadi, 2008: 19). Selain membuat peraturan dan undangundang, Indonesia juga membangun beberapa lembaga anti terorisme. Misalnya pembentukan Densus 88 dan melalui instruksi presiden no 4 tahun 2002 dibentuklah the Counter-Terrorism Coordinating Desk (CTCD) (Wise, 2005 : 38).

Amerika Serikat berhasil menjadikan wacana $W$ ar on Terror sebagai suatu aturan saat mereka berhasil mempengaruhi negara-negara untuk terlibat dan masuk dalam berbagai perjanjian untuk kerja sama perang melawan terorisme. Perjanjianperjanjian ini menjadi legitimasi untuk perang melawan terorisme. Legitimasi ini membuat negara- negara menyesuaikan diri dengan norma yang ada. Negara-negara mulai membuat undang-undangnya sendiri yang menunjukkan bahwa mereka merasa dan meyakini bahwa terorisme juga merupakan bahaya domestik. Negara-negara akhirnya menginternalisasi norma War on Terror dalam berbagai peraturan domestiknya dan meyakini bahwa dengan menerima norma ini mereka menunjukkan identitasnya sebagai anggota komunitas internasional. Negara-negara digerakkan oleh identitasnya sebagai anggota komunitas internasional dan oleh kepentingannya untuk mempertahankan dan menjaga keamanan nasional dan internasional serta menjunjung tinggi nilai kemanusiaan, kebebasan dan demokrasi oleh karena itu mereka menerima dan menginternalisasi $W$ ar on Terror sebagai aturan yang mengatur dinamika domestik meraka dan pola hubugan mereka dalam komunitas internasional.

Indonesia yang pada awal menolak War on Terror karena menganggap War on Terror adalah perang melawan Islam dan bahwa terorisme tidak mungkin menyerang Indonesia. Namun, peristiwa Bom Bali I menjadikan Indonesia menyadari bahwa terorisme ada dan merupakan ancaman domestik bagi Indonesia sendiri. Peristiwa bom Bali I menimbulkan perubahan tingkah laku dan pola pikir Indonesia terhadap $W$ ar on Terror. Indonesia mulai semakin gencar membangun kerja sama untuk melawan terorisme dan secara domestik membuat dan membangun berbagai lembaga dan aturan untuk mengatasi terorisme. Kenyataan ini juga menunjukkan bahwa Indonesia telah menginternalisasi War on Terror. Dengan menginstitusionalisasikan $W$ ar on Terror dalam berbagai undang-undang, peraturan dan membentuk lembaga khusus untuk $W$ ar on Terror, Indonesia menunjukkan bahwa 
telah menginternalisasi norma War on Terror dan dengan demikian menunjukkan identitasnya sebagai anggota komunitas internasional.

\section{Kesimpulan}

Wacana War on Terror menginternasionalisasi dan menginternalisasi karena suatu proses pengkonstruksian. Pengonstruksian memberikan identitas baru bagi aktor-aktor dalam hubungan internasional dan menghasilkan institusionalisasi wacana War on Terror sebagai norma (undang-undang dan peraturan) secara internasional dan domestik. Indonesia merupakan salah satu contoh negara yang menginternalisasi wacana $W$ ar on Terror menjadi norma domestiknya. Meskipun proses internalisasi di Indonesia mendapat tantangan namun peristiwa teror yang terjadi di Indonesia menjadikan proses internalisasi menjadi semakin cepat.

Dengan demikian konstruksi $W$ ar on Terror bukanlah sesuatu proses yang represif melainkan suatu reproduktif yang menghasilkan berbagai undang-undang dan peraturan, meyakinkan negara-negara di luar Amerika, misalnya negara-negara Uni Eropa dan Indonesia bahkan komunitas internasional bahwa terorisme bukan hanya mengancam dan atau hanya ada dan menyerang Amerika Serikat saja tetapi juga ada, mengancam dan menyerang negara-negara lain. Pada titik ini wacana $W a r$ on Terror telah menginternalisasi di berbagai negara di luar Amerika.

\section{Daftar Pustaka}

\section{Buku}

Folker, Jennifer Sterling. (2006). Contructivism dalam Jennifer Starling-Folker, Making Sense of International Relations Theory. London. Lynne Rienner Publishers, Inc.

Gee, James Paul. (2011). An Introduction to Discourse Analysis: Theory and method. Third Edition, New York: Routledge.

Indriana, Kartini dan Rosita Dewi. (2005). Upaya Peningkatan Hubungan Bilateral Indonesia-AS Pasca 9/11, dalam Awani Irewati, 2005 Hubungan Indonesia Amerika Serikat dalam menyikapi masalah terorisme pasca 9/11. Indonesia. Pusat Penelitian Politik, Lembaga Ilmu Pengetahuan 
Jackson, Robert. \& Goerg Sorensen. (2009). Pengantar Studi Ilmu Hubungan Internasional. Yogyakarta: Pustaka Pelajar.

Kean, Thomas H. (2002). The 9/11 Commission Report: Final Report of the National Commission on Terrorist Attacks Upon the United States, Washington DC.

Koechler, Hans. (2002). The War On Terror, Its Impact On The Sovereignty of States, and Its Implications for Human Right and Civil. Manila. Libertiea.

Neubert, Stefan \& Kersten Reich. (2002). Toward a Constructivist Theory of Discourse: Rethinking the Boundaries of Discourse Philosophy. University of Cologne.

Onuf, Nicholas Greenwood. (1989). World of Our Making: Rules and Rule in Social Theory and International Relations. South Carolina. University of South Carolina Press.

Puschkarsky, Tatjana. (2009). Norm Entrepreneurs in International Politics: A Case Study of Global Footprint Network and the Norm of Sustainability. Fakultas Ekonomi dan Ilmu Sosial Departemen Ilmu Politik. Universitas Heidelberg.

Ramakrishna, Kumar. \& Tan, See Seng ( eds). (2003). After Bali: The Threat of Terrorism in Southeast Asia. Singapore. Institute of Defence and Strategic Studies.

Reus-Smit, Christian. (2005). "Constructivism "dalam Scott Burchill. at all, 2005. Theories of International Relations, Third edition. New York: Palgrave Macmillan.

Reus-Smit. (2005). (eds), The Globalization Of World Politics: An Introduction to International Relations. New York: Oxford University Press.

Soetriadi, Ewit. (2008). Kebijkan Penanggulangan Tindak Pidana Terorisme dengan Hukum Pidana. Semarang.

Wise,William M. (2005). Indonesia's War on Terror, Washington, DC United StatesIndonesia Society.

Zehfuss, Maja. (2004). Constructivism in International Relations : The politics of reality. Cambridge: Cambridge University Press.

\section{Publikasi Ilmiah}


Archick, Kristin. (2011). U.S.-EU Cooperation Against Terrorism, CRS Report for Congress, Prepared for Members and Committees of Congress.

Asia-Pacific Security Studies. (2003). U.S.-Indonesia Relations: Searching for Cooperation in the War against Terrorism. Asia--Pacific Center for Security Studies Volume 2.

Desker, Barry. (2002). Islam and Society in Southeast Asia After September 11, Singapore. Institute of Defence and Strategic Studies.

Fulton, Wayne. (2004). Intelligence and the 'War against Terrorism': Multilateral CounterTerrorism Policies Implemented post-September 11, A dissertation submitted as partial requirement for the degree of: Master of Arts: International Relations. University of the Witwatersrand.

Kay, Lena. (2005). Indonesian Public Perceptions of the U.S. and Their Implications for U.S. Foreign Policy, Issues \& Insights Vol. 5 - No. 4 Pacific Forum .Hawaii. CSIS Honolulu.

Seniwati, Dr. Mohd. Azizuddin Mohd. Sani dan Prof. K. Nadaraja. (2012). Cooperation Between Indonesia and ASEAN to Counter Terrorism in Indonesia, Academic Research International Vol. 2, No. 1, January 2012

Solheim, Silje. (2006). Either You Are With Us, or You Are With the Terrorists ; A Discourse Analysis of President George W. Bush's Declared War on Terrorism. Master Thesis. Faculty Of Social Science, University Of Tromso.

Tumanggor, Robert Eryanto. (2007). Indonesia's Counter Terrorism Policy, UNISCI Discussion Papers, No 15 (Octubre / October 2007). Madrid.

Vaughn, Bruce. Coordinator.. (2005). Terrorism in Southeast Asia, CRS Report for Congress Updated February 7.

Włodarek, Łukasz. (2010). George W. Bush's War on Terror from a Political Discourse Perspective, Styles of Communication. Vol 2, No 1. Galati. Danubius: University Press.

\section{Artikel Daring}

Bush, Goerge W. (2001) (a) "Statement by the President in His Address to the Nation” Rilis 11 September 2001. Diakses pada 12 November 2011 dari http://www.whitehouse.gov/news/releases/2001/09/20010911-16.html 
Bush, Goerge W. (2001). (b) "Address to a Joint Session of Congress and the American People" Rilis September 20, 2001. Diakses pada 12 November 2011 dari http://www.whitehouse.gov/news/releases/2001/09/20010920-8.html

GAO (2008). “COMBATING TERRORISM: State Department's Antiterrorism Program Needs Improved Guidance and More Systematic Assessments of Outcomes". United States Government Accountability Office. February 2008. Diakses $14 \quad$ Mei 2012 pada http://www.gao.gov/new.items/d08336.pdf

Manan, Abdul. (2013). "Sejumlah Fakta Soal Peringatan Serangan 9/11”. Diakses 19 Mei 2017 pada https://m.tempo.co/read/news/2013/09/11/116512516/sejumlahfakta-soal- peringatan-serangan-9-11

Menteri Luar Negeri Indonesia. (2003) "Refleksi Tahun 2002 dan Proyeksi Tahun 2003”. Pernyataan Pers. Jakarta, 8 Januari 2003. Diakses 14 Mei 2012 pada http://www.kbricanberra.org.au/press/press030108i.htm

Siregar, Mahendra. (2001). Pidato Megawati 19 September 2001: Address By H.E. Megawati Soekarnoputri President Republic Of Indonesia At Usindo Gala Dinner, Washington DC, 19 September 2001, Wed, 19 Sep 2001 22:00:45 -07:00. Diakses 29 Mei 2017 pada http://www.mailarchive.com/permias@listserv.syr.edu/msg12675.html

UN Security Council (2013). "The Counter-Terrorism Committee (CTC)". Diakses 14 Mei 2012 pada http://www.un.org/en/sc/ctc/ dan http://www.un.org/en/sc/ctc/aboutus.html

Uni Eropa (n.d.). "EU Plan of Action on Combating Terrorism". Diakses 14 Mei 2012 pada http://ue.eu.int/uedocs/cmsUpload/EU_PlanOfAction10586.pdf

Voa Indonesia (2002). “Amerika Melancarkan Kampanye Iklan Sebagai Toleransi Terhadap Islam". Diakses 14 Mei 2012 pada http:/ /www.voaindonesia.com/content/a-32-a-2002-10-31-8-185284027/47539.html 